\title{
Determination of organochlorine compounds in coastal marine sediments from the southern west of the Mediterranean Sea
}

\author{
${ }^{1 *}$ D. Fouial-Djebbar; ${ }^{2}$ A. Y. Badjah-Hadj Ahmed; ${ }^{3}$ H. Budzinski \\ ${ }^{1}$ Faculty of Chemistry, University of Sciences and Technology Houari Boumediene, BP 32 El-Alia, 16111, \\ Bab-Ezzouar, Algiers, Algeria \\ ${ }^{2}$ Faculty of Chemistry and Laboratory of Functional Organic Analysis, University of Sciences and Technology \\ Houari Boumediene, BP 32 El-Alia, 16111, Bab-Ezzouar, Algiers, Algeria \\ ${ }^{3}$ Bordeaux 1 University and Laboratory of Physico and Toxico Chemistry of Natural Systems, ISM - UMR 5255, \\ Université de Bordeaux 1, 351 cours de la Libération, 33405 Talence, France
}

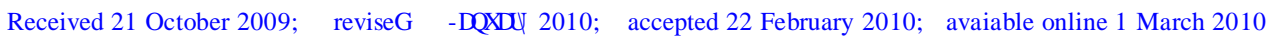

\begin{abstract}
Recent evidence suggests that polychlorinated biphenyls might also have adverse reproductive, developmental and endocrine effects. Although, the use of polychlorobiphenyls in Algeria has been banned for more than two decades, large quantities of these compounds containing products remain disseminated, mainly stored in obsolete or damaged equipments. This research describes a study to assess polychlorinated biphenyls distribution in marine sediments collected from the seaside of Tamentfoust touristic resort located in the eastern side of Algiers Bay. After microwave-assisted extraction and purification with both concentrated sulphuric acid and activated silica gel, the extracts were analyzed by gas chromatography with an electron capture detector. Relatively high contamination levels of polychlorinated biphenyls were found in samples collected from the port of Tamentfoust (15 to $70 \mathrm{ng} / \mathrm{g} \mathrm{d}$.w.), while the concentrations were lower in the stations located outside the port ( 0 to $26 \mathrm{ng} / \mathrm{g} \mathrm{d.w.).} \mathrm{Compared} \mathrm{with} \mathrm{data}$ previously reported by some other researchers, the polychlorobiphenyls concentrations found in this work showed an environmental persistence, but a decrease of approximately 5 times in 30 year i.e since the ban of the use of polychlorinated biphenyls. The predominant polychlorinated biphenyls congeners in all sediment samples were polychlorinated biphenyls138, 153, 180 and 187. This composition was similar to industrial mixture (Aroclor 1260). This probably indicated that the contamination originated from the port and has a continental source.
\end{abstract}

Keywords: Environment; Extraction; Gas chromatography; Polychlorinated biphenyls

\section{INTRODUCTION}

Polychlorinated biphenyls (PCBs) are persistent organic pollutants with significant bioaccumulation potentials in environmental systems (UNEP, 2003). These compounds are frequently detected in a wide variety of environmental matrices such as sediments, soils, biota, water and air, in both industrial and nonindustrial areas (Iwata et al., 1995; Floch et al., 1996; Bodin et al., 2004). The synthesis of PCBs was first described in 1881 (Schmidt and Schultz, 1881). Their wide industrial application started from 1930 because of their chemical stability including nonflammability and heat resistance properties (Erickson, 1997). They have been used as dielectric fluids in capacitors and transformers, hydraulic fluids, lubricating oils,

*Corresponding Author Email: djebbar_djamila@yahoo.fr Tel./Fax: +213 21247311 plasticisers, additives in pesticides, inks and paints (Gervason, 1987; Edward Raja and Selvam, 2009). The presence of PCBs in the environment was first identified in biological samples in 1966 (Jensen, 1966). PCBs have long been identified as harmful substances due to their toxicity (Safe, 1992, Persson et al., 2005, Sporveri et al., 2007; Juang et al., 2009a; b). In the Mediterranean Sea, there have been numerous studies investigating the environmental fate and distribution of PCBs particularly in the northern side (Spain, France, Italy) (Tolosa et al., 1997). However, information on the spatial and temporal distribution of PCBs in the southern Mediterranean countries remains poor. Recently, some papers described investigations on PCBs observed in Egypt (Barakat et al., 2002, Tundo et al., 2004, Said, 2007), Tunisia (Pavoni et al., 2000) 
and Morocco (Pavoni et al., 2001). In Algeria, PCBs were widely used mainly as dielectric fluids in the past 50 years and some still remain in use or in storage (6699 apparatus containing over 3443 tons of Askarel oil have been inventoried) (Ministère de l'Aménagement du Territoire et de l'Environnement, 2006). Although this class of compounds were banned in 1987 (decree 87-182 issued on 18 August 1987), the distribution of PCBs andtheir effects on environment and human health havenot been widely studied since data published by Elder and Villeneuve (1977) and Cousteau (1979). In the other hand, ISMAL (Institut des Sciences Marines et de l’Aménagement du Littoral) located in Algiers, has contributed to UNEP programs for Mediterranean Sea protection. The aim of this study was to assess the level and distribution of PCBs in marine sediment samples collected from the seaside of Tamentfoust resort (La Perouse) located in the eastern side of Algiers Bay. In this district, tourist activities take place while the number of inhabitants increases markedly during the summer period. Six sampling campaigns were carried out from July to October 2002 in the Tamentfoust port and in four locations situated outside the port.

\section{MATERIAL AND METHODS}

\section{Sample collection}

Thirty coastal marine sediment samples were collected from five sites located at the port and on both sides at $3 \mathrm{~m}$ (locations 2 and 5) and $10 \mathrm{~m}$ depth (locations 3 and 4 ) as described in Fig. 1. An aerial view of Tamentfoust Port is shown on Fig. 2. Sediments were freeze-dried and stored in sealed containers. All the samples were analyzed at the Laboratory of Physics and Toxicological Chemistry (LPTC), Bordeaux1 University, France.

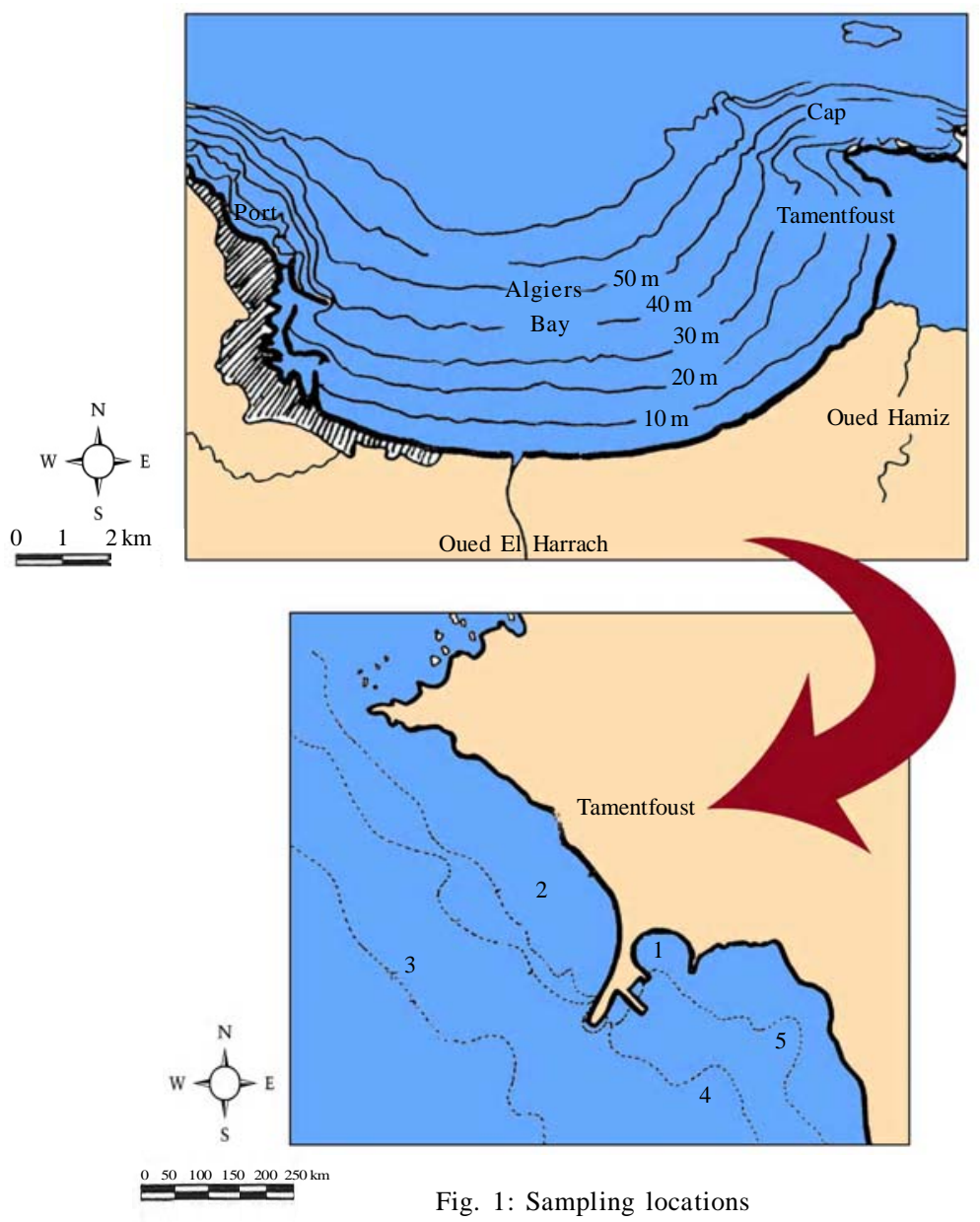




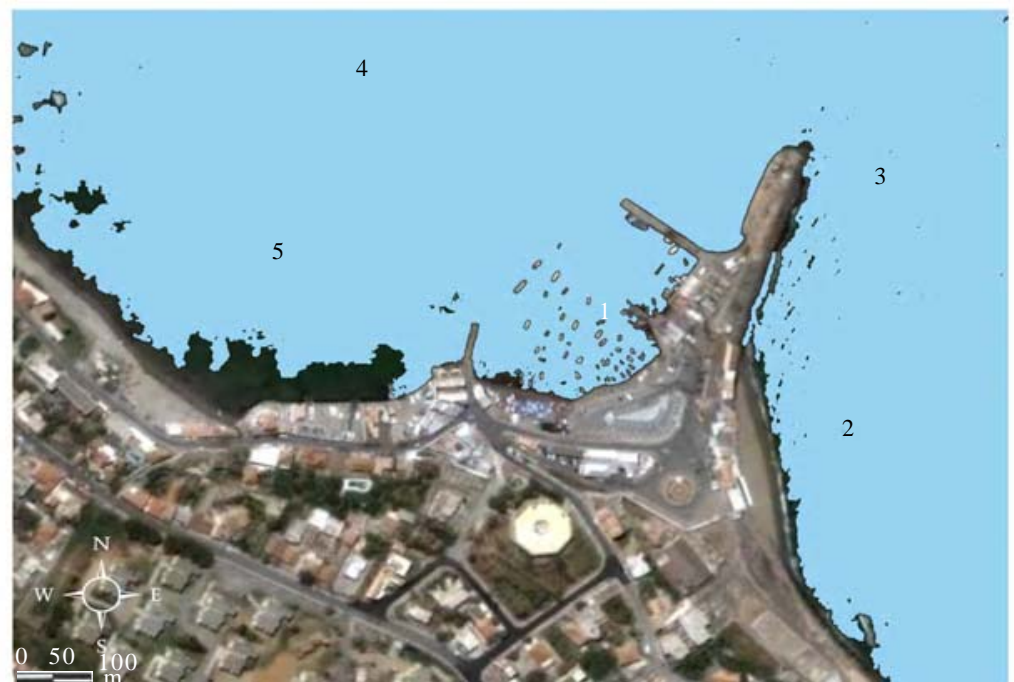

Fig. 2: Aerial view of Tamentfoust Port (from Google earth, 2009)

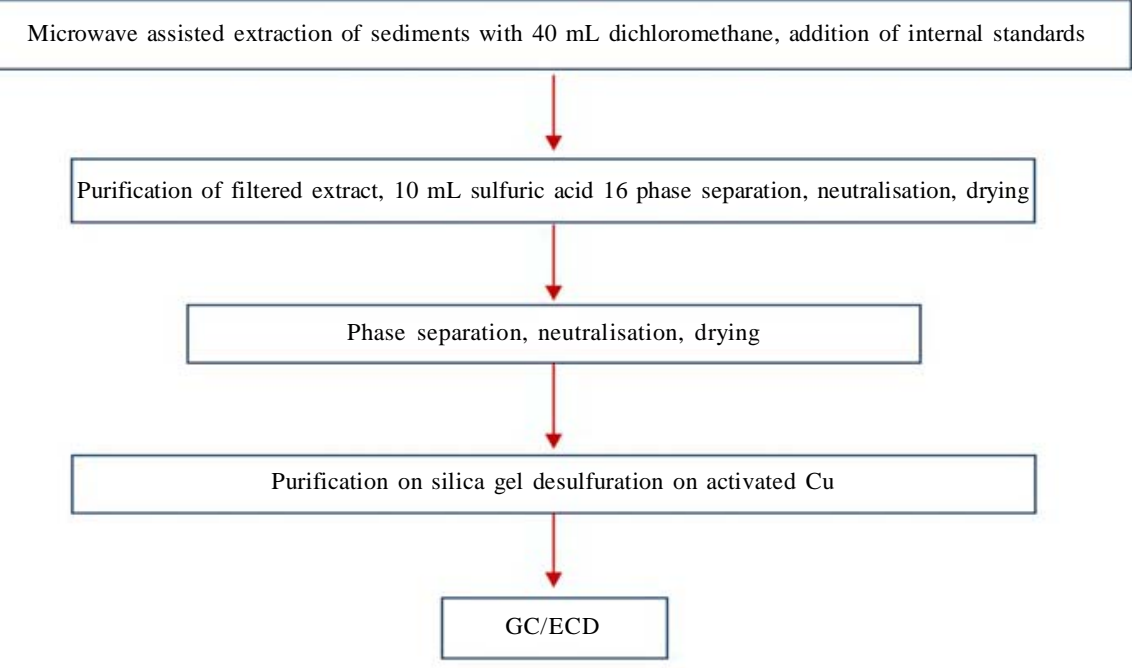

Fig. 3: The procedure of sample preparation

\section{Sample preparation}

The experimental procedure is summarized in Fig. 3. All samples were sieved through $2 \mathrm{~mm}$ to homogenize sediments prior to the extraction. The surrogate standards PCB30, PCB103, PCB155, PCB198 and octachloronaphthalene (OCN) were added to the sediment before extraction. The sample ( $5 \mathrm{~g}$ mass of dry sediment) was extracted by microwave-assisted extraction (Letellier, 1999; Budzinski et al., 2000; Thompson and Budzinski, 2000) with $40 \mathrm{~mL}$ of dichloromethane using a Magidigest 350 Prolabo apparatus at a $15 \mathrm{~W}$ power and for $10 \mathrm{~min}$. After extraction, the sample was filtered and purified with concentrated sulphuric acid. The organic and acid phases were separated and the organic extract was diluted with pure water and dried over anhydrous sodium sulfate. The extract was concentrated under a gentle flow of nitrogen then purified a second time on a column packed with activated silica $(2 \mathrm{~g})$ and $1 \mathrm{~cm}$ of activated copper on top for elimination of elemental 
sulfur. The PCBs were eluted from this column with $3 \times$ $5 \mathrm{~mL}$ 10:90 dichloromethane-pentane. The extract was concentrated under nitrogen and transferred to $0.5 \mathrm{~mL}$ isooctane. The solution was further re-concentrated to $0.05 \mathrm{~mL}$ in a conical injection vial. The same procedure was used for the blank sample which was run with every set of five samples to check for secondary contamination.

\section{Chemical reagents}

The PCBs standards were purchased from Promochem (Promochem, Molsheim, France) in solution at $99 \%+$ purity. The surrogate standards PCB 30, 103, 155 and 198 and OCN were also obtained from Promochem (Promochem, Molsheim, France) as crystals of $99 \%$ + purity. A certified solution of PCB, SRM 2262 was obtained from NIST (Gaithersburg, MD, USA). Dichloromethane was purchased from Prolabo (Prolabo, Fontenay sous Bois, France, pesticide grade). The anhydrous sodium sulfate and the concentrated acid were from Fluka Chemie (Buchs, Switzerland), and the silica gel (particle size 0.063-0.2 mm) from Merck (Darmstadt, Germany). The copper (40 meshes, 95.5\% purity) was purchased from Aldrich (Aldrich,
Strasbourg, France). Isooctane of spectroscopy grade quality and HPLC grade pentane were from Scharlau, ICS (St. Médard en Jalles, France).

\section{Gas chromatography}

The extract was analyzed by GC-ECD on a HewlettPackard 5890 Series II gaschromatograph equipped with a ${ }^{63} \mathrm{Ni}$ electron-capture detector using a HP5 capillary column $(60 \mathrm{~m} \times 0,25 \mathrm{~mm}$ i.d. $\times 0,25 \mu \mathrm{m}$ film thickness). The GC conditions were as follows: splitless injection $(1 \mu \mathrm{L})$; injector temperature: $280^{\circ} \mathrm{C}$; detector temperature: $290^{\circ} \mathrm{C}$; initial oven temperature: $60^{\circ} \mathrm{C}$ held for $2 \mathrm{~min}$, heated to $120^{\circ} \mathrm{C}$ at $6^{\circ} \mathrm{C} / \mathrm{min}$ and held for $5 \mathrm{~min}$, then heated to $280^{\circ} \mathrm{C}$ at $2^{\circ} \mathrm{C} / \mathrm{min}$ and held for $20 \mathrm{~min}$. Helium was used as the carrier gas. The PCB congeners were analyzed individually when possible, though in some cases the concentrations are reported as the sum of overlapping congeners due to coelution on the GC column. The relative response factors of different compounds were determined after each six samples by injecting a standard solution of PCBs (Table 1) spiked with the same solution of internal standards (PCB30, PCB103, PCB155, PCB198 and OCN)

Table 1: List of the studied PCBs and their corresponding internal standards

\begin{tabular}{|c|c|c|}
\hline Internal standards & Chemical name & IUPAC nomenclature \\
\hline PCB30 & 2,4'-dichlorobiphenyl & PCB 8 \\
\hline PCB30 & 2,2',5-trichlorobiphenyl & PCB 18 \\
\hline PCB30 & 2, 4,5-trichlorobiphenyl & PCB 29 \\
\hline PCB30 & 2, 4,4'-trichlorobiphenyl & PCB 28 \\
\hline PCB30 & 2,2',4,6-tetrachlorobiphenyl & PCB 50 \\
\hline PCB103 & 2,2',5,5' - tetrachlorobiphenyl & PCB 52 \\
\hline PCB103 & 2,2',4,6,6'-pentachlorobiphenyl & PCB 104 \\
\hline PCB103 & 2,2',3,5'-tetrachlorbiphenyl & PCB 44 \\
\hline PCB155 & 2,3',4,4'-tetrachlorobiphenyl & PCB 66 \\
\hline PCB155 & 2,2',4,5,5'-pentachlorobiphenyl & PCB 101 \\
\hline PCB155 & 2,2',3,4,5'-pentachlorbiphenyl & РCB 87 \\
\hline PCB155 & 3,3',4,4'-tetrachlorobiphenyl & PCB 77 \\
\hline PCB155 & 2,2',4,4',5,6-hexachlorobiphenyl & PCB 154 \\
\hline PCB198 & 2,3',4,4',5-pentachlorobiphenyl & PCB 118 \\
\hline PCB198 & $2,2^{\prime}, 3,4^{\prime}, 5,6,6^{\prime}$-heptachlorobiphenyl & PCB 188 \\
\hline PCB198 & 2,2',4,4'5,5'-hexachlorobiphenyl & PCB 153 \\
\hline PCB198 & 2,3,3',4,4'-pentachlorobiphenyl & PCB 105 \\
\hline PCB198 & 2,2',3,4,4',5',6-hexachlorobiphenyl & PCB 138 \\
\hline PCB198 & 3,3',4,4',5-pentachlorobiphenyl & PCB 126 \\
\hline PCB198 & 2,2',3,4',5,5',6-heptachlorobiphenyl & PCB 187 \\
\hline PCB198 & 2,2',3,3',4,4'-hexachlorobiphenyl & PCB 128 \\
\hline PCB198 & $2,2^{\prime}, 3,3^{\prime}, 4,5,6,6^{\prime}$-octachlorobiphenyl & PCB 200 \\
\hline PCB198 & $2,2^{\prime}, 3,4,4^{\prime}, 5,5^{\prime}$-heptachlorobiphenyl & PCB 180 \\
\hline PCB198 & $2,2^{\prime}, 3,3^{\prime}, 4,4^{\prime}, 5$-heptachlorobiphenyl & PCB 170 \\
\hline PCB198 & 2,2', 3,3',4,4',5,6-octachlorobiphenyl & PCB 195 \\
\hline PCB198 & 2,2',3,3',4,4',5,5',6-nonachlorobiphenyl & PCB 206 \\
\hline PCB198 & $2,2^{\prime}, 3,3^{\prime}, 4,4^{\prime} 5,5^{\prime}, 6,6^{\prime}$-decachlorobiphenyl & PCB 209 \\
\hline
\end{tabular}


as that used for spiking the samples. Blank injections of isooctane were performed before each sample injection to ensure the cleanliness of the injector. A certified solution of PCB, SRM 2262 obtained from NIST (MD, USA) was used. The limit detection was $0.01 \mathrm{ng}$.

\section{RESULTS AND DISCUSSION}

The concentrations of the PCBs in sediments are reported in Table 2 for the location 1, in Table 3 for the locations 2 and 5 and in Table 4 for the locations 3 and 4. All concentrations data are based on dry weight. The mean recovery of PCBs from three replicate sediment samples was $95 \%$. Twenty PCB congeners were detected at the port, sixteen in the locations two (2) and five (5) and fourteen in the locations 3 and 4 . As example, two chromatograms of the PCBs extracts obtained in $30^{\text {th }}$ day at locations 1 and 5 are shown in Fig. 4.

PCB8, PCB66, PCB126, PCB188 and PCB209 were not detected in any of the samples. Individual PCB concentrations of samples collected from the port were higher for congeners substituted with 5, 6 and 7 chlorine atoms (Table 2). In the same station, a $12 \mathrm{ng} / \mathrm{g}$ maximum concentration value was found for PCB138 (60 th day), and this extract corresponded to the most contaminated sample with a total PCB content of 70 $\mathrm{ng} / \mathrm{g}$. It has been also focused on the seven priority congeners which are known for their persistence in environment samples: PCBs 28, 52, 101, 118, 138, 153 and 180. In this study, the total seven PCBs priority concentrations ranged from 0.11 to $38 \mathrm{ng} / \mathrm{g}$ as shown in Fig. 5. They represented $50 \%$ to $62 \%$ of total PCBs in location 1 (the port) and $50 \%$ to $100 \%$ in the other locations.

Among the collected samples, the 12 sediments collected from the locations 2 and 3 were bulky. The particle size distribution of the 18 others was determined by laser. For the locations 4 and 5, the size of sediments was $63 \%$ to $98 \%$ below $650 \mu \mathrm{m}$. The sediment samples collected from the location 1 (the port) were fine, with particle sizes below $125 \mu \mathrm{m}$.

\section{PCBs levels in sediments}

The sum of total PCBs concentrations in marine sediments samples collected from Tamentfoust basin ranged from 0 to $70 \mathrm{ng} / \mathrm{g}$ dry weight (Tables 2, 3 and 4) were lowest compared to some data collected during the last years in Mediterranean coast (Table 5). Indeed,

Table 2: Concentrations (ng/g d.w.) of PCBs for samples collected from location one (1) (the port at 2.5m depth)

\begin{tabular}{|c|c|c|c|c|c|c|}
\hline Days & 0 day & $15^{\text {th. }}$ day & $30^{\text {th. }}$ day & $45^{\text {th. }}$ day & $60^{\text {th. }}$ day & $85^{\text {th. }}$ day \\
\hline PCB 8 & ND & ND & ND & ND & ND & ND \\
\hline PCB 18 & 0.11 & 0.01 & 0.20 & 0.17 & 0.01 & 0.17 \\
\hline РCB 29 & 0.25 & 0.01 & 0.01 & 0.17 & 0.01 & 0.01 \\
\hline PCB 50+28 & 0.01 & 0.01 & 0.30 & 0.01 & 0.37 & 0.50 \\
\hline PCB 52 & 0.33 & 3.21 & 1.72 & 3.33 & 2.68 & 1.22 \\
\hline PCB 104 & 0.01 & 0.01 & 0.01 & nd & 0.21 & 0.01 \\
\hline PCB 44 & 0.19 & 1.03 & 0.44 & 1.29 & 0.67 & 0.36 \\
\hline PCB 66 & ND & ND & ND & ND & ND & ND \\
\hline PCB 101 & 1.15 & 4.20 & 4.24 & 6.77 & 5.81 & 3.41 \\
\hline PCB 87 & 1.28 & 1.62 & 3.74 & 2.87 & 3.84 & 4.83 \\
\hline PCB $154+77$ & 1.35 & 6.54 & 5.53 & 10.63 & 7.95 & 4.89 \\
\hline РСB 118 & 0.99 & 4.65 & 3.75 & 7.32 & 5.37 & 3.16 \\
\hline PCB 188 & ND & ND & ND & ND & ND & ND \\
\hline PCB 153 & 2.67 & 3.25 & 8.67 & 4.84 & 10.56 & 4.01 \\
\hline PCB 105 & 0.01 & 0.01 & 1.41 & 4.55 & 0.01 & 0.01 \\
\hline PCB 138 & 2.23 & 1.32 & 8.30 & 6.63 & 11.69 & 6.32 \\
\hline PCB 126 & ND & ND & ND & ND & ND & ND \\
\hline PCB 187 & 0.90 & 4.48 & 3.08 & 0.71 & 6.37 & 3.23 \\
\hline PCB 128 & 0.43 & 3.68 & 1.63 & 1.74 & 4.81 & 1.57 \\
\hline PCB 200 & 0.01 & 0.01 & 0.44 & nd & 1.61 & 0.30 \\
\hline PCB 180 & 1.62 & 4.12 & 5.32 & 1.29 & 1.83 & 4.76 \\
\hline PCB 170 & 0.90 & 3.92 & 2.67 & 0.74 & 5.59 & 3.11 \\
\hline PCB 195 & 0.13 & 1.27 & 0.41 & ND & 0.50 & 0.37 \\
\hline PCB 206 & 0.06 & 0.40 & 0.20 & ND & 0.63 & 0.15 \\
\hline РCB 209 & ND & ND & $\mathrm{ND}$ & ND & ND & ND \\
\hline Total PCBs & 15 & 46 & 54 & 53 & 70 & 42 \\
\hline$\sum 7$ PCBs & 9 & 20 & 32 & 30 & 38 & 23 \\
\hline
\end{tabular}

ND: Non detected 
D. F. Djebbar et al.

Table 3: Concentrations (ng/g d.w.) of PCBs for samples collected from locations 2 and 5 (at 3 m depth)

\begin{tabular}{|c|c|c|c|c|c|c|c|c|c|c|c|c|}
\hline Dates & \multicolumn{2}{|c|}{0 day } & \multicolumn{2}{|c|}{$15^{\text {th. }}$ day } & \multicolumn{2}{|c|}{$30^{\text {th. }}$ day } & \multicolumn{2}{|c|}{$45^{\text {th. }}$ day } & \multicolumn{2}{|c|}{$60^{\text {th. }}$ day } & \multicolumn{2}{|c|}{$85^{\text {th. }}$ day } \\
\hline Locations & 2 & 5 & 2 & 5 & 2 & 5 & 2 & 5 & 2 & 5 & 2 & 5 \\
\hline PCB8 & ND & ND & ND & ND & ND & ND & ND & ND & ND & ND & ND & ND \\
\hline PCB 18 & ND & ND & ND & ND & ND & ND & ND & ND & ND & ND & ND & ND \\
\hline РCB 29 & 0.31 & 0.01 & 0.01 & 0.01 & 0.01 & 0.50 & 0.01 & 0.01 & 0.01 & 0.01 & 0.01 & 0.01 \\
\hline PCB $50+28$ & 0.01 & 0.10 & 0.01 & 0.01 & 0.01 & 0.01 & 0.01 & 0.02 & 0.01 & 0.07 & 0.01 & 0.06 \\
\hline PCB 52 & 0.09 & 0.33 & 0.03 & 0.02 & 0.01 & 0.09 & 0.06 & 0.14 & 0.47 & 0.49 & 0.05 & 0.10 \\
\hline PCB 104 & 0.01 & 0.01 & 0.01 & 0.01 & 0.01 & 0.02 & 0.01 & 0.01 & 0.01 & 0.01 & 0.01 & 0.08 \\
\hline PCB 44 & 0.01 & 0.07 & 0.15 & 0.01 & 0.01 & 0.01 & 0.01 & 0.06 & 0.12 & 0.10 & 0.03 & 0.10 \\
\hline PCB 66 & ND & ND & ND & ND & ND & ND & ND & ND & ND & ND & ND & ND \\
\hline PCB 101 & 0.37 & 0.30 & 0.96 & 0.04 & 0.06 & 0.14 & 0.16 & 0.28 & 0.73 & 0.49 & 0.12 & 0.26 \\
\hline PCB 87 & 0.26 & 0.03 & 0.54 & 0.30 & 0.04 & 0.23 & 0.05 & 0.20 & 0.32 & 0.25 & 0.04 & 0.16 \\
\hline PCB & 0.01 & 0.01 & 0.45 & 0.01 & 0.01 & 0.08 & 0.23 & 0.30 & 0.73 & 0.54 & 0.38 & 0.21 \\
\hline $154+77$ & & & & & & & & & & & & \\
\hline PCB 118 & 0.04 & 0.66 & 0.66 & 0.01 & 0.01 & 0.01 & 0.04 & 0.12 & 0.28 & 0.01 & 0.07 & 0.01 \\
\hline PCB 188 & ND & ND & ND & ND & ND & ND & ND & ND & ND & ND & ND & ND \\
\hline PCB 153 & 0.34 & 0.92 & 0.91 & 0.37 & 0.19 & 0.60 & 0.21 & 0.52 & 0.73 & 0.43 & 0.11 & 0.52 \\
\hline PCB 105 & 0.19 & 0.15 & 0.70 & 0.04 & 0.06 & 0.63 & 0.01 & 0.21 & 0.20 & 0.01 & 0.14 & 0.01 \\
\hline PCB 138 & 0.29 & 0.90 & 0.87 & 0.33 & 0.13 & 0.49 & 0.18 & 0.32 & 0.75 & 0.29 & 0.18 & 0.32 \\
\hline PCB 126 & ND & ND & ND & ND & ND & ND & ND & ND & ND & ND & ND & ND \\
\hline PCB 187 & 0.10 & 0.44 & 0.31 & 0.23 & 0.09 & 0.27 & 0.10 & 0.18 & 0.25 & 0.16 & 0.03 & 0.17 \\
\hline PCB 128 & 0.07 & 0.01 & 0.23 & 0.01 & 0.01 & 0.07 & 0.06 & 0.01 & 0.16 & 0.02 & 0.07 & 0.08 \\
\hline PCB 200 & ND & ND & ND & ND & ND & ND & ND & ND & ND & ND & ND & ND \\
\hline PCB 180 & 0.10 & 0.33 & 0.31 & 0.34 & 0.20 & 0.34 & 0.16 & 0.27 & 0.33 & 0.27 & 0.10 & 0.24 \\
\hline PCB 170 & 0.05 & 0.09 & 0.33 & 0.18 & 0.10 & 0.30 & 0.11 & 0.17 & 0.28 & 0.11 & 0.09 & 0.20 \\
\hline PCB 195 & ND & ND & ND & ND & ND & ND & ND & ND & ND & ND & ND & ND \\
\hline PCB 206 & ND & ND & ND & ND & ND & ND & ND & ND & ND & ND & ND & ND \\
\hline PCB 209 & ND & ND & ND & ND & ND & ND & ND & ND & ND & ND & ND & ND \\
\hline Total PCBs & 2 & 4 & 6 & 2 & 1 & 4 & 1 & 3 & 5 & 3 & 1 & 3 \\
\hline$\sum 7 \mathrm{PCBs}$ & 1 & 4 & 4 & 1 & 1 & 2 & 1 & 2 & 3 & 2 & 1 & 1 \\
\hline
\end{tabular}

ND: Non detected

Table 4: Concentrations (ng/g d.w.) of PCBs for samples collected from locations 3 and 4 (at 10 m depth)

\begin{tabular}{|c|c|c|c|c|c|c|c|c|c|c|c|c|}
\hline Dates & \multicolumn{2}{|c|}{0 day } & \multicolumn{2}{|c|}{$15^{\text {th. }}$ day } & \multicolumn{2}{|c|}{$30^{\text {th. }}$ day } & \multicolumn{2}{|c|}{$45^{\text {th. }}$ day } & \multicolumn{2}{|c|}{$60^{\text {th. }}$ day } & \multicolumn{2}{|c|}{$85^{\text {th. }}$ day } \\
\hline Locations & 3 & 4 & 3 & 4 & 3 & 4 & 2 & 5 & 2 & 5 & 2 & 5 \\
\hline PCB 8 & ND & ND & ND & ND & ND & ND & ND & ND & ND & ND & ND & ND \\
\hline PCB 18 & ND & ND & ND & ND & ND & ND & ND & ND & ND & ND & ND & ND \\
\hline РCВ 29 & ND & ND & ND & ND & ND & ND & 0.01 & 0.01 & 0.01 & 0.01 & 0.01 & 0.01 \\
\hline PCB 50+28 & 0.26 & 0.32 & 0.05 & 0.01 & 0.01 & 0.20 & 0.01 & 0.02 & 0.01 & 0.07 & 0.01 & 0.06 \\
\hline PCB 52 & 0.18 & 0.21 & 0.01 & 0.28 & 0.06 & 0.54 & 0.06 & 0.14 & 0.47 & 0.49 & 0.05 & 0.10 \\
\hline PCB 104 & ND & ND & ND & ND & ND & ND & 0.01 & 0.01 & 0.01 & 0.01 & 0.01 & 0.08 \\
\hline PCB 44 & 0.01 & 0.01 & 0.01 & 0.06 & 0.01 & 0.08 & 0.01 & 0.06 & 0.12 & 0.10 & 0.03 & 0.10 \\
\hline PCB 66 & ND & ND & ND & ND & ND & ND & ND & ND & ND & ND & ND & ND \\
\hline РCB 101 & 0.01 & 0.01 & 0.03 & 0.71 & 0.10 & 0.92 & 0.16 & 0.28 & 0.73 & 0.49 & 0.12 & 0.26 \\
\hline РCB 87 & 0.16 & 0.01 & 0.11 & 0.69 & 0.07 & 1.03 & 0.05 & 0.20 & 0.32 & 0.25 & 0.04 & 0.16 \\
\hline PCB 154+77 & 1.64 & 0.57 & 0.06 & 1.00 & 0.01 & 1.06 & 0.23 & 0.30 & 0.73 & 0.54 & 0.38 & 0.21 \\
\hline РСВ 118 & 0.01 & 0.11 & 0.11 & 0.82 & 0.03 & 0.72 & 0.04 & 0.12 & 0.28 & 0.01 & 0.07 & 0.01 \\
\hline РCB 188 & ND & ND & ND & ND & ND & ND & ND & ND & ND & ND & ND & ND \\
\hline PCB 153 & 0.30 & 0.43 & 0.29 & 0.85 & 0.30 & 2.46 & 0.21 & 0.52 & 0.73 & 0.43 & 0.11 & 0.52 \\
\hline РСВ 105 & 0.01 & 0.14 & 0.02 & 0.60 & 0.10 & 0.01 & 0.01 & 0.21 & 0.20 & 0.01 & 0.14 & 0.01 \\
\hline PCB 138 & 0.43 & 0.85 & 0.05 & 0.62 & 0.07 & 2.15 & 0.18 & 0.32 & 0.75 & 0.29 & 0.18 & 0.32 \\
\hline PCB 126 & ND & ND & ND & ND & ND & ND & ND & ND & ND & ND & ND & ND \\
\hline РCB 187 & 0.16 & 0.15 & 0.07 & 0.18 & 0.08 & 1.24 & 0.10 & 0.18 & 0.25 & 0.16 & 0.03 & 0.17 \\
\hline РCB 128 & 0.01 & 0.01 & 0.05 & 0.14 & 0.06 & 0.37 & 0.06 & 0.01 & 0.16 & 0.02 & 0.07 & 0.08 \\
\hline РCB 200 & ND & ND & ND & ND & ND & ND & ND & ND & ND & ND & ND & ND \\
\hline РCB 180 & 0.14 & 0.05 & 0.19 & 0.27 & 0.10 & 0.96 & 0.16 & 0.27 & 0.33 & 0.27 & 0.10 & 0.24 \\
\hline РCB 170 & 0.01 & 0.01 & 0.21 & 0.17 & 0.06 & 0.54 & 0.11 & 0.17 & 0.28 & 0.11 & 0.09 & 0.20 \\
\hline РCB 195 & ND & ND & ND & ND & ND & ND & ND & ND & ND & ND & ND & ND \\
\hline РСВ 206 & ND & ND & ND & ND & ND & ND & ND & ND & ND & ND & ND & ND \\
\hline РCB 209 & ND & ND & ND & ND & ND & ND & ND & ND & ND & ND & ND & ND \\
\hline Total PCBs & 3 & 3 & 1 & 6 & 1 & 12 & 1 & 3 & 5 & 3 & 1 & 3 \\
\hline$\sum 7$ PCBs & 1 & 2 & 1 & 4 & 1 & 8 & 1 & 2 & 3 & 2 & 1 & 1 \\
\hline
\end{tabular}

ND: Non detected 

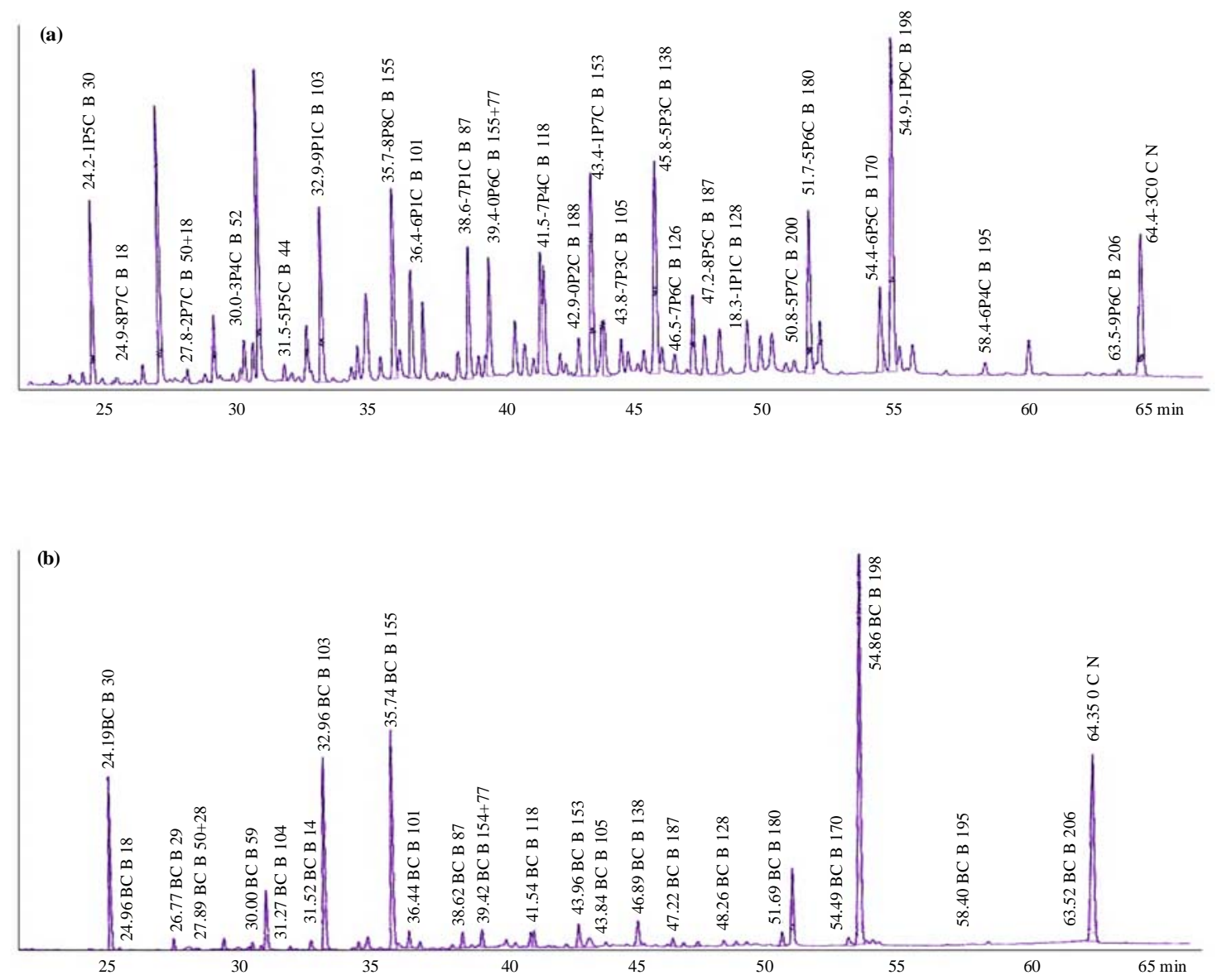

Fig. 4: Chromatograms of the PCBs extract obtained at $30^{\text {th. }}$ day (a: Location 1; b: Location 5)
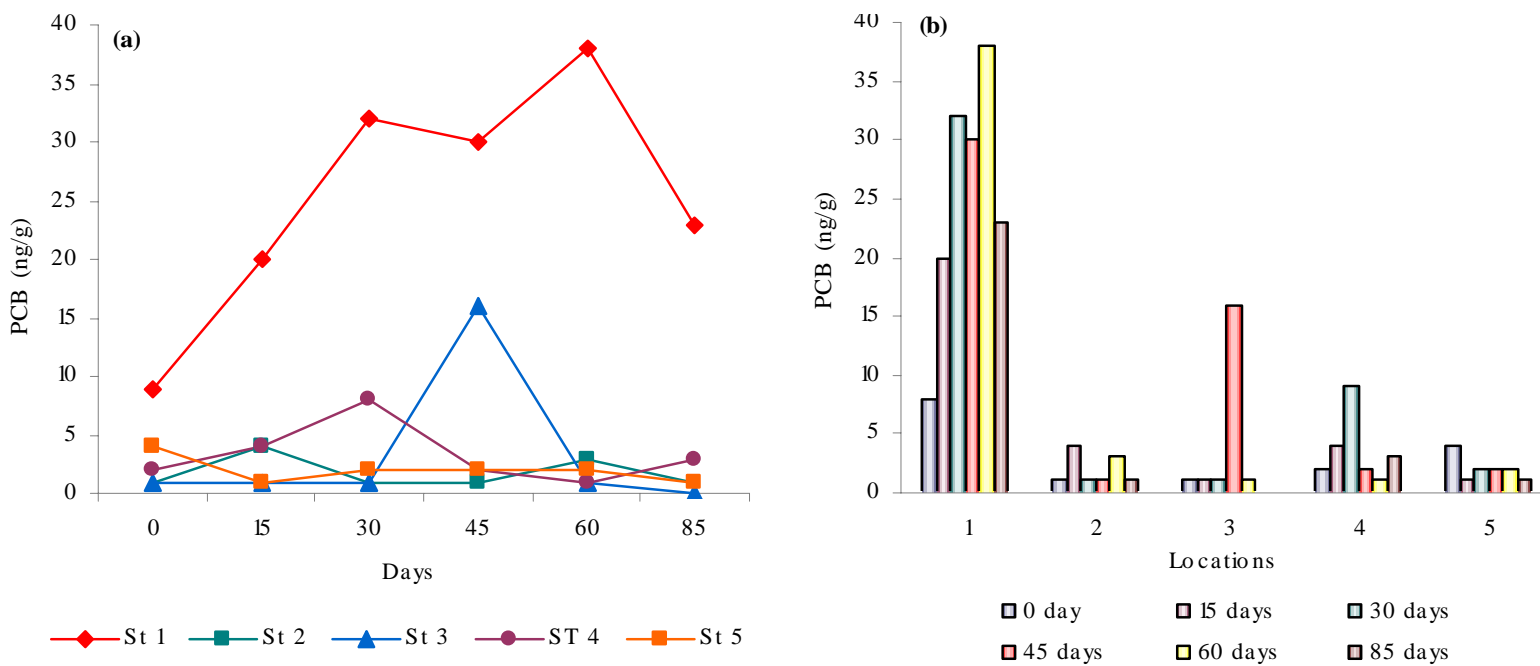

Fig. 5: Concentrations of the seven priority PCBs (a: Over the studied period; b: At the five locations) 
Determination of organochlorine compounds in coastal marine sediments

Table 5: Comparison of PCB levels determined in sediments from different Mediterranean regions

\begin{tabular}{lll}
\hline Location & ng/g d.w. & Reference \\
\hline Tamentfoust port, Algiers Bay, Algeria & $0.31-70$ & The present work \\
Algerian coast & 9 & Elder et Villeneuve, 1975 \\
Algerian coast & $7-323$ & Cousteau, 1979 \\
Arrone River, central Italy & $10-200$ & Bazzanti et al., 1997 \\
Sousse, Tunisian coast & 40 & Pavoni et al., 2000 \\
Alexandria Harbour, Egypt ${ }^{\mathrm{a}}$ & $0.9-1210$ & Barakat et al., 2002 \\
Temsah Lake, Suez Canal, Egypt ${ }^{\text {b }}$ & $0.039-43.201$ & Tundo et al., 2004 \\
Port of Bagnoli, Gulf of Naple, south Italy & $4-100$ & Romano et al., 2004 \\
Keratsini Harbour, Saronikos Gulf, Greece & $47.8-351.8$ & Galanopoulou et al., 2005 \\
Cortiou, Marseille, France & $12.68-1559.3$ & Wafo et al., 2006 \\
Naple Harbour, south Italy & $1-889$ & Sprovieri et al., 2007 \\
Western Coast of Alexandria, Egypt & $0.79-64.9$ & Said, 2007 \\
Coastal Barcelona, Spain & $2.33-44$ & Castells et al., 2008 \\
Near submarine emissary, Barcelona & $22.34-37.74$ & Castells et al., 2008 \\
\hline
\end{tabular}

a: Surface sediments, b: Concentration of PCB118, c: Sum of 38 congeners

in some cases these levels could reach $1559,3 \mathrm{ng} / \mathrm{g}$ dry weight in Marseille (Wafo et al., 2006), $1210 \mathrm{ng} / \mathrm{g}$ in Alexandria (Barakat et al., 2002) and 889 ng/g in Naple (Sproveri et al., 2007). In the past (1977), high levels of contamination with PCBs were found close to Algiers. Thus, $323 \mathrm{ng} / \mathrm{g}$ of Aroclor were found in marine sediments within an area of $10 \mathrm{~km}$ from Algiers (Cousteau, 1979). Compared with this data, the PCBs concentrations found in this work showed an environmental persistence but a decrease of approximately 5 times in $30 \mathrm{y}$, i.e since the ban of the use of PCBs. These data did not reach the threshold concentrations established by some governments as France (Brunet et al., 2007).

\section{Composition of PCBs}

The composition of the different extracts was very similar to a slight fluctuation of the total PCBs content over the studied period, except for the sample collected at location three in September which corresponded to a total concentration of $26 \mathrm{ng} / \mathrm{g}$. It was probably due to an accidental spill. The highest PCBs concentrations (70 $\mathrm{ng} / \mathrm{g}$ ) were recorded in sediment samples collected from the port (location 1). These PCBs have been probably emitted from a continental source in addition to the port activities. Off shore, PCBs high levels were $12 \mathrm{ng} / \mathrm{g}$ (location 4, $10 \mathrm{~m}$ depth) and $26 \mathrm{ng} / \mathrm{g}$ (location 3, $10 \mathrm{~m}$ depth).This let us to suppose that the contamination of locations situated off shore was originated from the port. This hypothesis was supported by the similar PCBs profile found at all locations and throughout the studied period. The PCBs congeners constituting this profile were ranged from trichloro to nonachlorobiphenyl. The most concentrated contaminants were PCBs 153, 138, 187 and 180 which are either hexa or heptasubstituted. This composition of individual PCBs in the sediments was most similar to the industrial mixture Aroclor 1260 as it was previously reported by some authors (Schultz, 1989; Bazzanti et al., 1997). Indeed, it is thought that PCBs congeners in sediments closely resemble parent industrial mixture unless modified by bacterial mediated degradation (Brown and Wager, 1990). Compared to the reference matrix, light PCBs such as PCB8 in location 1, PCB8 and PCB18 in locations two and five, PCB8, PCB18 and PCB29 in locations three and four were not detected. This could be explained by their probable volatilization during storage and during analytical procedure. Indeed, the less chlorinated congeners are more volatile than the higher chlorinated congeners (Thompson et al., 2002). Futhermore, PCBs with a higher number of chlorine atoms are more stable in the marine environment since they undergo less readly enzymatique oxydation by bacteria (Abramowicz et al., 1993). Moreover, beacause of there lower solubility in water, highly chlorinated PCBs are preferentially associated to the sediments (Mangani et al., 1991). On the other hand, PCB195 (heptachlorosubstituted) and PCB200 (octachloro-substituted) were only detected at the port. This could be related to the influence of the different sediment grain size fractions in sorbing and releasing PCBs as reported by Thompson et al. (1996), Edgar et al. (2003). According to Pierard et al. (1996), high chlorinated PCBs are preferentially associated with finer particle sizes of sediment fractions, while less chlorinated congeners are found with the bulky ones. As data shows, the particles sediment samples collected from the port were finer $(<125 \mu \mathrm{m})$ that those collected from the other locations.

\section{CONCLUSION}

The results of this study demonstrate that the PCBs concentrations remains still persistent in the marine 
environment despite the ban of their production and use. These concentrations did not show significant fluctuations throughout the short studied period. Compared to the previous results reported for other Mediterranean industrial and urban concentrations, the levels of polychlorobiphenyls determined in the sediments in this region of Algiers Bay can be considered as moderate. The profile of the PCBs was very close to that of Aroclor 1260 mixture formerly used in electrical transformers, hydraulic fluids, plasticizer in synthetic resins and dedusting agents. Although the production and sale in Algeria was discontinued in late 1987, it is still present in many of the transformers and capacitors now in use. Relatively, high contamination levels of PCBs were found in samples collected from the port of Tamentfoust while the concentrations were much lower in the stations located outside the port. In addition, the chromatographic profiles of the different extracts showed a similar composition which probably indicates that the contamination originates from the port. However, it is necessary to emplement measures to control industial waste decharge and to avoid dispersal of these persistent toxic contaminants into the environment (Nouri et al., 2008). Additional, since the very few investigations realized on PCBs in Algeria, further research work should be performed in order to establish a more detailed assessment of the target compounds levels in this area.

\section{ACKNOWLEDGEMENTS}

This research was supported by the University of Houari Boumediene, Algiers, Algeria. This study was achieved with the kind assistance of the Laboratory of Physics and Toxico-Chemistry (LPTC), University of Bordeaux1, France. The authors are grateful to Pr. Hélène BUDZINSKI, Research Director and all the laboratory team.

\section{REFERENCES}

Abramowics, D. A.; Brennan, M. J.; Van Dort, H. M.; Gallagher, E. L., (1993). Factors influencing the rate of polychlorinated biphenyl dechlorination in Hudson River sediments. Environ. Sci. Tech., 27 (6), 1125-1131 (7 pages).

Abdallah, A. M. A.; Ha, A.; El-Seba, A., (1998). Level of chlorinated hydrocarbons in a teleost fish and a bivalve from the Egyptian Mediterranean Coast and Nile Estuary. Z. Lebensm Unters Forch A, 206 (1), 25-28 (4 pages).

Barakat, A. O.; Kim M.; Qian, Y.; Wade, T. L., (2002). Organochlorine pesticides and PCB residues in sediments of Alexandria harbour, Egypt. Marine Pollut. Bull., 44 (12), 1426-1434 (9 pages).

Bazzanti, M.; Chiavarini, S.; Cremisini, C.; Soldati, P., (1997). Distribution of PCB congeners in aquatic ecosystems: A case study. Environ. Int., 23 (6), 799-813 (15 pages).
Bodin, N.; Burgeot, T.; Stanisière, J. Y.; Bocquené, G.; Menard, D.; Minier, C.; Boutet, I.; Amat, A.; Cherel, Y.; Budzinski, H., (2004). Seasonal variations of a battery of biomarkers and physiological indices for the mussel Mytilus galloprovincialis transplanted into the northwest Mediterranean Sea. Comparat. Biochem. Physiol. Part C, 138 (4), 411-427 (17 pages).

Brown, J. F.; Wager, R. E., (1990). PCB movement, dechlorination and detoxication in the Acushnet Estuary. Environ. Toxicol. Chem., 9 (10), 1215-1233 (19 pages).

Brunet, J. F., (2007). Etat des lieux sur la pollution des fleuves par les PCB dans le monde. BRGM/RP 55835-FR, 167.

Budzinski, H.; Letellier, M.; Thompson, S.; LeMenach, K.; Garrigues, P., (2000). Combined protocol for the analysis of polycyclic aromatic hydrocarbons (PAHs) and polychlorobiphenyls (PCBs) from sediments using focused microwave assisted (FMW) extraction at atmospheric pressure. Fresenius Anal. Chem., 367 (2), 165-171 (7 pages).

Castells, P.; Parera, J.; Santos, F. J.; Galceran, M. T., (2008). Occurrence of polychlorinated naphthalenes, polychlorinated biphenyls and short-chain chlorinated paraffins in marine sediments from Barcelona (Spain). Chemosphere, 70 (9), 1552-1562 (11 pages).

Cousteau, J. Y., (1979). Rapport préliminaire de l'expédition C.I.E.S.M.-Cousteau Society effectuée par le navire Calypso pour contribuer à l'établissement d'un « bulletin de santé » de la Méditerranée. IV ${ }^{\text {es }}$ Journées études pollutions, Antalya, 21-31.

Edgar, P. J.; Hursthouse, A. S.; Matthews, J. E.; Davies, I. M., (2003). An investigation of geochemical factors controlling the distribution of PCBs in intertidal sediments at a contamination hot spot, the Clyde Estuary, UK. Appl. Geochem., 18 (2), 327-338 (12 pages).

Edward Raja, C.; Selvam, G. S., (2009). Plasmid profile and curing analysis of Pseudomonas aeruginosa as metal resistant. Int. J. Environ. Sci. Tech., 6 (2), 259-266 (7 pages).

Elder, D. L.; Villeneuve, J. P., (1977). Polychlorinated biphenyls in marine air, deep sediments, and water of the Mediterranean Sea. Thalassia Jugoslavia, 13, 59-62 (7 pages).

Erickson, M. D., (1997). Analytical chemistry of PCBs, second ed, CRC Press, Boca Raton FL, 667.

Floch, I. ; Vaquero, M. T.; Comellas, L.; Broto-Puig, F., (1996). Extraction and clean-up methods for improvement of the chromatographic determination of polychlorinated biphenyls in sewage sludge-amended soils: Elimination of lipids and sulphur. J. Chromatogr A., 719 (1), 121-130 (10 pages).

Galanopoulou, S.; Vgenopoulos, A.; Conispoliatis, N., (2005). DDTs and other chlorinated organic pesticides and polychlorinated biphenyls pollution in the surface sediments of Keratsini harbour, Saronikos Gulf, Greece. Marine PollutionBulletin, 50 (5), 520-525 (6 pages).

Gervason, P., (1987). PCB : leurs propriétés et leurs applications dans l'électrotechnique. Revue Générale de l'Electricité (RGE), 8, 5-11 (6 pages).

Iwata, H.; Tanabe, S.; Armato, M.; Ueda, K.; Tatsukawa, R., (1995). Persistent organochlorine residues in air, water, sediments and soil from the lake Baikal Region, Russia. Environ. Sci. Tech., 29 (3), 792-801 (10 pages).

Jensen, S., (1966). Report of a new chemical hazard. New Scientist, 32, 612.

Juang, D. F.; Lee, C. H.; Hsueh, S. C., (2009a). Chlorinated volatile organic compounds found near the water surface of heavily polluted rivers. Int. J. Environ. Sci. Tech., 6 (4), 
545-556 (12 pages).

Juang, D. F.; Yuan, C. S.; Hsueh, S. C.; Chiou, L. J., (2009b). Distribution of volatile organic compounds around a polluted river. Int. J. Environ. Sci. Tech., 6 (1), 91-104 (14 pages).

Letellier, M.; Budzinski, H., (1999). Microwave assisted extraction of organic compounds. Analusis, 27 (3), 259-271 (14 pages)

Magnani, F.; Crescentini, G.; Sisti, E.; Bruner, F.; Cannarsa, S., (1991). PAHs, PCB and Chlorinated Pesticides in Mediterranean coastal sediments. Int. J. Environ. Anal. Chem., 45 (2), 89-100 (12 pages).

Nouri, J.; Karbassi, A. R.; Mirkia, S., (2008). Environmental management of coastal regions in the Caspian Sea. Int. J. Environ. Sci. Tech., 5 (1), 43-52 (10 pages).

Pavoni, B.; Berto, D.; Rigoni, M.; Salizzato, M., (2000). Micro pollutants and organic carbon concentrations in surface and deep sediments in the Tunisian Coast near the city of Sousse. Marine Environ. Res., 49 (2), 177-196 (20 pages).

Pavoni, B.; Mecozzi, M.; Berto, D.; Ausili, A.; Romano, E.; Amici, M.; Zharova, N.; Amato, E., (2001). Environmental pollutants and organic carbon content in sediments from an area of the Moroccan Mediterranean coast. Toxicol. Environ. Chem., 84 (1-4), 53-67 (15 pages).

Persson, N. J.; Gustafsson, O.; Bucheli, T. D.; Ishaq, R.; Naes, K.; Broman, D., (2005). Distribution of PCNs, PCBs, and other POPs together with soot and other organic matter in the marine environment of the Grenlandsfjords, Norway. Chemosphere, 60 (2), 274-283 (10 pages).

Piérard, C.; Budzinski, H. ; Garrigues, P ., (1996). Grain size distribution of PCBs in coastal sediments. Environ. Sci. Tech., 30 (9), 2776-2783 (8 pages).

Romano, E. ; Ausili, A. ; Zharova, N. ; Magno, M. C. ; Pavoni, B.; Gabellini, M., (2004). Marine sediment contamination of an industrial site at port of Bagnoli, Gulf of Naples, Southern Italy. Marine Pollut. Bull., 49 (5-6), 487-495 (9 pages).

Safe, S., (1992). Development, validation and limitations of toxic equivalent factors. Chemosphere, 25 (1-2), 61-64 (4 pages).

Said, T. O., (2007). Determination of persistent organic pollutants in sediment of the western coast of Alexandria, Egypt. Chem. Eco., 23 (4), 289-302 (14 pages).

Schmidt, H.; Schultz, G., (1881). Einwirkung von FiinffachChlorphosphor auf das y- diphenol. Ann. Chim, 207, 338344 (7 pages).
Schultz, D. E.; Petrick, G.; Duinker, J. C., (1989). Complete characterization of polychlorinated biphenyl congeners in commercial Aroclor and Clophen mixtures by multidimentional gas chromatography-electron capture detection. Environ. Sci. Tech., 23 (7), 852-859 (8 pages).

Sprovieri, M.; Feo, M. L.; Prevedello, L.; Salvagio manta, D.; Sammartino, S.; Marsella, E., (2007). Heavy metals, polycyclic aromatic hydrocarbons and polychlorinated biphenyls in surface sediments of the Naples harbor (southernItaly). Chemosphere, 67 (5), 998-1009 (12 pages).

Thompson, A. ; Alen, J. R. ; Dodoo, D.; Hunter, J.; Hawkins, S. J.; Wolff, G. A., (1996). Distribution of polychlorinated biphenyls in mussels and sediments from Great Britain and Irish Sea Coast. Mar. Pollut. Bull., 32 (2), 232-237 (6 pages).

Thompson, S.; Budzinski, H., (2000). Determination of polychlorinated biphenyls and chlorinated pesticides in environmental biological samples using focused microwaveassisted extraction. Int. J. Environ. Anal. Chem., 76 (1), 4960 (12 pages)

Thompson, S.; Budzinski, H.; LeMenach, K.; Letellier, M.; Garrigues, P., (2002). Multi-residue analysis of polycyclic aromatic hydrocarbons, polychlorobiphenyls and organochlorine pesticides in marine sediments. Anal. Bioanal. Chem., 372 (1), 196-204 (8 pages).

Tolosa, I.; Readman, J. W.; Fowler, S. W.; Villeneuve, J. P.; Dachs, J.; Bayona, J. M.; Albaiges, J., (1997). PCBs in the western Mediterranean: Temporal trends and mass balance assessment. Deep-Sea Res. PT. II, 44 (3-4), 907-928 (22 pages).

Tundo, P.; Raccanelli, S.; Reda, L. A.; Ahmed, M. T., (2004). Distribution of polychlorinated dibenzo-p-dioxins, polychlorinated dibenzofurans, dioxin-like polychlorinated biphenyls and polycyclic aromatic hydrocarbons in the sediment of temsah lake, Suez Canal, Egypt. Chem. Eco., 20 (4), 257-265 (9 pages).

UNEP/MAP, (2003). Riverine transport of water, sediments and pollutants to the Mediterranean Sea, MAP technical reports series, Athens, Greece, 141.

Wafo, E.; Sarrazin, L.; Diana, C., Schembri, T.; Lagadec, V; Monod, J. L., (2006). Polychlorinated biphenyls and DDT residues distribution in sediments of Cortiou (Marseille, France). Marine Pollut. Bull., 52 (1), 104-107 (4 pages).

\section{AUTHOR (S) BIOSKETCHES}

Fouial-Djebbar, D., Ph.D. Candidate, Laboratory of Functional Organic Analysis, Faculty of Chemistry, University of Sciences and Technology Houari Boumediene, BP 32 El-Alia, 16111, Bab-Ezzouar, Algiers, Algeria. Email: djebbar djamila@yahoo.fr

Badjah Hadji Ahmed, A. Y., Full Professor, Faculty of Chemistry and research director in Laboratory of Functional Organic Analysis, University of Sciences and Technology Houari Boumediene, BP 32 El-Alia, 16111, Bab-Ezzouar, Algiers, Algeria. Email: ybadjah@hotmail.com

Budzinski, H., Full Professor, Bordeaux 1 University and research director at Laboratory of Physico and Toxico Chemistry of Natural Systems, ISM - UMR 5255, Université de Bordeaux 1, 351 cours de la Libération, 33405 Talence, France.

Email: h.budzinski@lptc.u-bordeaux1.fr

How to cite this article: (Harvard style)

Fouial-Djebbar, D.; Badjah Hadji Ahmed, A. Y.; Budzinski, H., (2010). Determination of organochlorine compounds in coastal marine sediments from the southern west of the Mediterranean Sea. Int. J. Environ. Sci. Tech., 7 (2), 271-280. 